KAWISTARA

VOLUME 5

No. 3, 22 Desember 2015

Halaman 221-328

\title{
A COMPARISON BETWEEN SATOYAMA AND THE AINU WAY OF LIFE
}

\author{
Devon Dublin and Noriyuki Tanaka \\ Graduate School of Environmental Science \\ Hokkaido University, Hokkaido Japan \\ Email:devdub@ees.hokudai.ac.jp
}

\begin{abstract}
ABSTRAK
Tulisan ini membandingkan konsep Satoyama dengan Ainu, dengan sudut pandang membangun kesamaan budaya, ekologi, dan ekonomis antara mereka dan untuk menguji dampak dari perkembangan Hokkaido pada ekologi manusia Ainu. Penelitian dilakukan di Semenanjung Noto, dan wilayah Hidaka dari Hokkaido. Data dikumpulkan melalui wawancara individu, rumah tangga dan kelompok, survei kuesioner, kunjungan lapangan, dan dokumentasi yang tersedia. Hasil penelitian menunjukkan praktek-praktek pertanian, ekologi, dan budaya-spiritual yang identik untuk Satoyama dan Ainu. Kajian menunjukkan bahwa perkembangan Hokkaido menghasilkan peningkatan yang diperlukan dalam pertanian di masyarakat Ainu karena itu tidak mungkin lagi untuk hidup berkelanjutan hampir seluruhnya dari karunia alam; yang berlaku untuk masyarakat adat secara global. Kami mengandaikan bahwa kesamaan ini memberikan titik masuk yang layak untuk promosi Satoyama jika akan digunakan sebagai model perkembangan untuk mempromosikan pengenalan praktek pertanian baru, efektif, dan berkelanjutan yang disesuaikan dengan budaya lokal dan pengetahuan tradisional yang ada. Sehingga pembangunan dilihat dari sudut komunitas adat yang berkelanjutan secara global jarang terjadi karena sistem modern dipraktekkan saat ini cermin begitu erat budaya asli tradisional.
\end{abstract}

Kata Kunci: Satoyama; Ainu; Pertanian; Ekologi; Bentang Alam.

\begin{abstract}
This study compares the concept of Satoyama with that of the Ainu, with a view of establishing the cultural, ecological and economical similarities between them and to examine the impact of the development of Hokkaido on the Ainu human ecology. Research was conducted in the Noto Peninsula, and the Hidaka region of Hokkaido. Data was collected through individual, household and group interviews, questionnaire surveys, field visits and available documentation. Results revealed agricultural, ecological and cultural-spiritual practices that were synonymous to Satoyama and that of the Ainu. Research showed that the development of Hokkaido resulted in a necessary increase in agriculture in the Ainu communities since it was no longer possible to live sustainably almost entirely from the gifts of nature; which holds true for indigenous peoples globally. We posit that these commonalities provide a viable entry point for the promotion of Satoyama if it is to be used as a developmental model for promoting the introduction of new, effective and sustainable agricultural practices that are tailored to suit the local culture and existing traditional knowledge, with a view of building sustainable indigenous communities globally, since it is infrequent that modern systems practiced today mirror so closely traditional indigenous culture.
\end{abstract}

Keywords: Satoyama; Ainu; Agriculture; Ecology; Landscape. 


\section{INTRODUCTION}

Satoyama is a term for landscapes that comprise a mosaic of different ecosystems which include forests, agricultural lands, grassland irrigation ponds and human settlements aimed at promoting viable human nature interaction (Duraiappah and Nakamura, 2012). When one considers the landscape of the archipelago of Japan, one would encounter striking similarities between the various islands. Therefore, any community irrespective of their location may have developed similar relationships with their natural surroundings. Research conducted so far with respect to the Ainu points to a differing way of life to that of the Japanese. But were they that different? This paper seeks to answer this question with respect to the Ainu, and whether there were similar tendencies between their way of life during the Edo period (1615-1868), and that of the originators of $\mathrm{Sa}$ toyama in the mainland of Japan in the 1800s and which was subsequently introduced into Hokkaido.

During Japan's long and rich history, its landscape has transformed significantly and at one time did not include what is now known today as Hokkaido (Enomoto and Kimi, 1990). Shakushain an Ainu leader managed to fight against the conquest of the island in an attempt to keep it in Ainu hands but the Tokugawa Shogunate managed to finally solidify the Japanese presence on the island (Walker, 2001).

According to Walker (2001), Shakushain warned the Ainu that if Ezo was subjugated, the shogunate would introduce peasants to Wajinchi and encourage the development of agriculture, fisheries and organized hunting. In other words, he was adverting that the system to be introduced by the Japanese would be of a different perspective to that of the Ainu but was he correct? The Meiji regime, among other things, banned the Ainu from hunting in their ancestral hunting-grounds and imposing fishing restrictions. In 1899, the Law for the Protection of Former Hokkaido Aborigines was enacted which resulted in them becoming mainly small farmers (Howell, 1994).
Currently, the Hidaka region of Hokkaido, Japan which covers $4,811.91 \mathrm{~km}^{2}$, houses approximately $37.7 \%$ of persons of Ainu descent in Japan, the highest in any given area based on a 1999 census (Figure 1). The Hidaka Mountains are known as a "Mecca of Mountaineering", with more than 20 mountains including Mount Poroshiri at 2,052 metres $(6,732 \mathrm{ft})$. These mountains are part of the Hidaka Sanmyaku-Erimo Quasi-National Park, which include Mount Apoi alpine vegetation community and Cape Erimo coast landscape. These areas boast wildlife such as brown bear, sika deer, and common seal.

When the Hokkaido Development Commission was established in 1869 , the human population was 58,000 . In the initial phase of the development program, emigrants harvested large quantities of construction timber, developed new agricultural land, and gathered a massive amount of firewood and charcoal in preparation for the severe winter through clearing the forests on the outskirts of their residential area. From the 1880s onwards, the rapidly increasing numbers of emigrants caused an increase in timber harvesting (Aikoh et al., 2012). Wetlands along the rivers were filled or dried to expand the agricultural land base. Rivers were straightened and their banks cemented to protect new paddy fields along the lowlands from erosion and flooding (Ono, 1999).

As the agricultural development expanded and the almost total extinction of the deer population, the Ezo wolf (Canis lupus hattai) became a problem. Their usual prey, the deer had disappeared and as a result they attacked the farm animals resulting in bounty hunting supported by the Meiji government and massive poisoning by strychnine recommended by Edwin Dun. The last wolf was killed in 1896 (Walker, 2004). So development altered the ecosystem drastically, in contrast to the Ainu, who saw wildlife and hunting as a necessary part of their civilization. It is this model of agriculture based primarily on rice cultivation that is promoted as the original model of Japanese peasant society (Ohnuki-Tierney, 1993). 


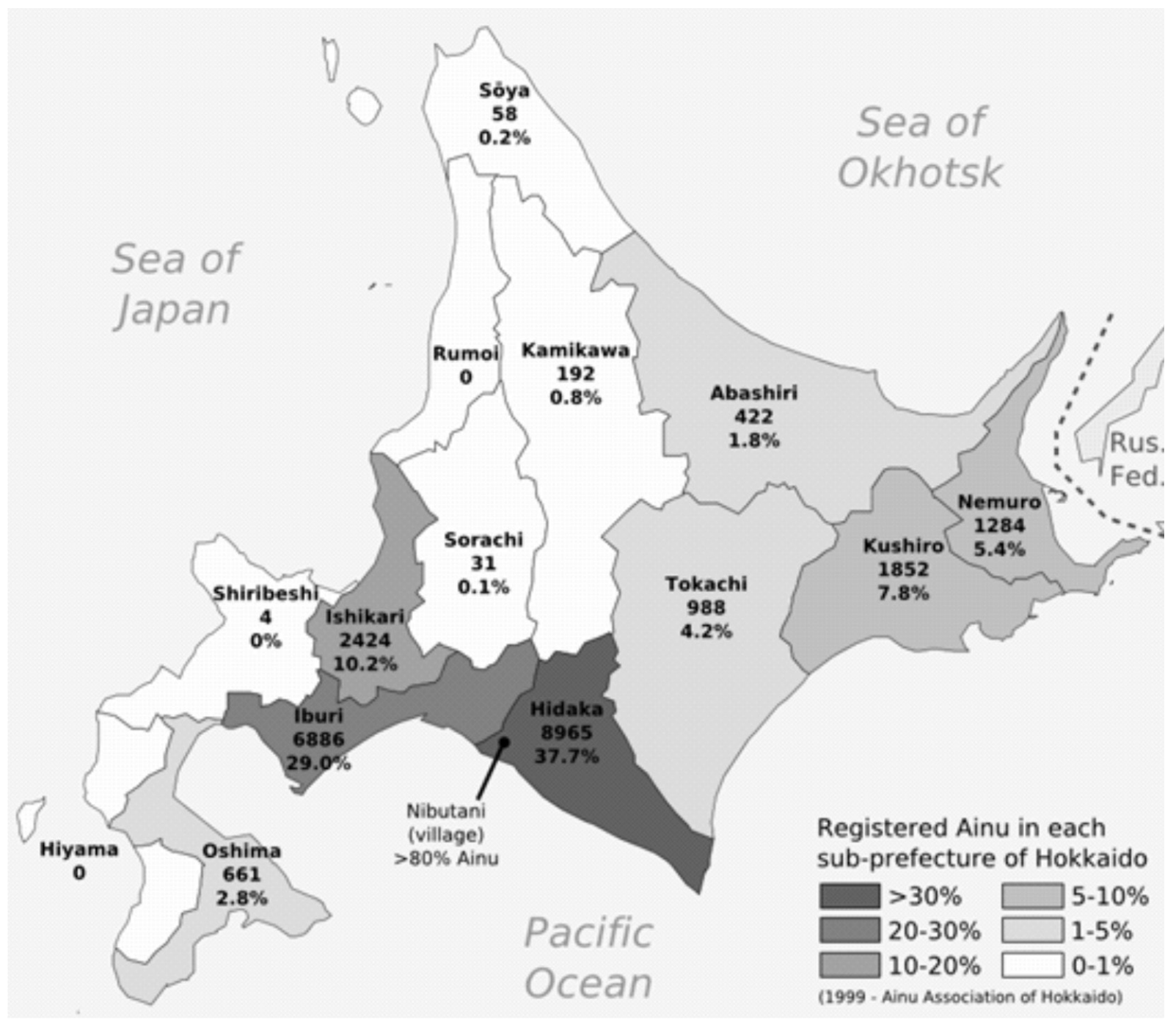

Figure 1. Map of Ainu in Hokkaido [1999]

(Source: Platon, 2013)

The development and modernization of Hokkaido included the Japanese government's agricultural resettlement policy which transformed the Ainu's traditional way of life. However, after the harvesting of vast quantities of timber for construction, clearing of forested areas for agricultural land, and the use of large quantities of firewood and charcoal especially during the winter, a movement for the protection of the natural resources of Hokkaido evolved. This resulted in the development of the Satoyama of Hokkaido (Aiko et al., 2012). Although not considered as typical satoyama landscapes as witnessed in Honshu, the land management system practiced in the initial development phase provided many key ecosystem services. A movement to protect Hokkaido's natural resources emerged and the natural capital remains in abundance even today when compared with Honshu. The climate, topography, history and the rapid development in Hokkaido produced a very different landscape to the mosaic structure seen commonly in Honshu. In Hokkaido, the term satoyama is used in the wider sense to refer to the forests which are close to living areas in addition to natural and artificial forests Aikoh et al. (2012).

Was this movement in any way a return to what the Ainu was practicing originally? We seek to answer this question in this 
study. This article begins by comparing the Ainu with the Satoyama of Suzu in the Noto Peninsula from the perspective of landscape use. We then make a comparison on the basis of the use of the ecosystem benefits derived from the human nature interaction. A comparison is then made from a cultural spiritual perspective.
The study of the Ainu was conducted in Samani town located in the Hidaka region of Hokkaido, Japan (Figure 2). It has an area of $364.33 \mathrm{~km}^{2}$ and a current population of 5,029 as of March 31st, 2012 (Japan Autonomous Academy, 2012). It was chosen because of the high percentage of persons of Ainu descent that currently live there.

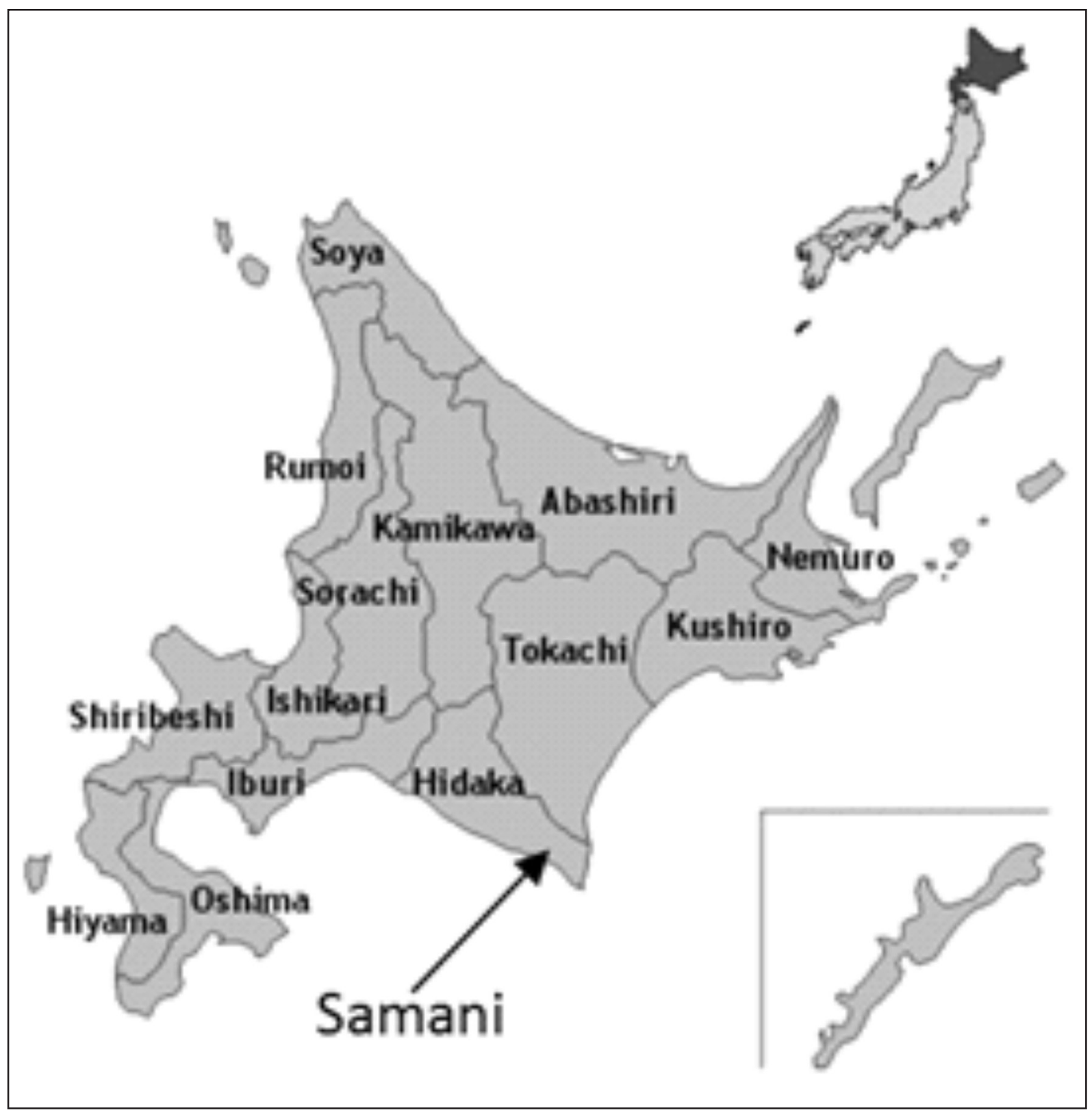

Figure 2. Location of Samani Town (Source: Hokkaido Government, 2013) 
The study of Satoyama was conducted in the city of Suzu located in the Noto peninsula of Ishikawa Prefecture, Japan (Figure 3). It covers $1,866 \mathrm{~km}^{2}$ and homes approximately 189,000 households. This location was selected because it is one of the areas in which the Satoyama way of life developed. This area houses the Satoyama
Satoumi office that is staffed and works in conjunction with the Kanazawa University. The area is also famous for the Senmai$d a$, an area that conducts rice cultivation on terraced slopes and the community received accreditation as a Globally Important Agricultural Heritage Site (GIAHS) in June 2011.

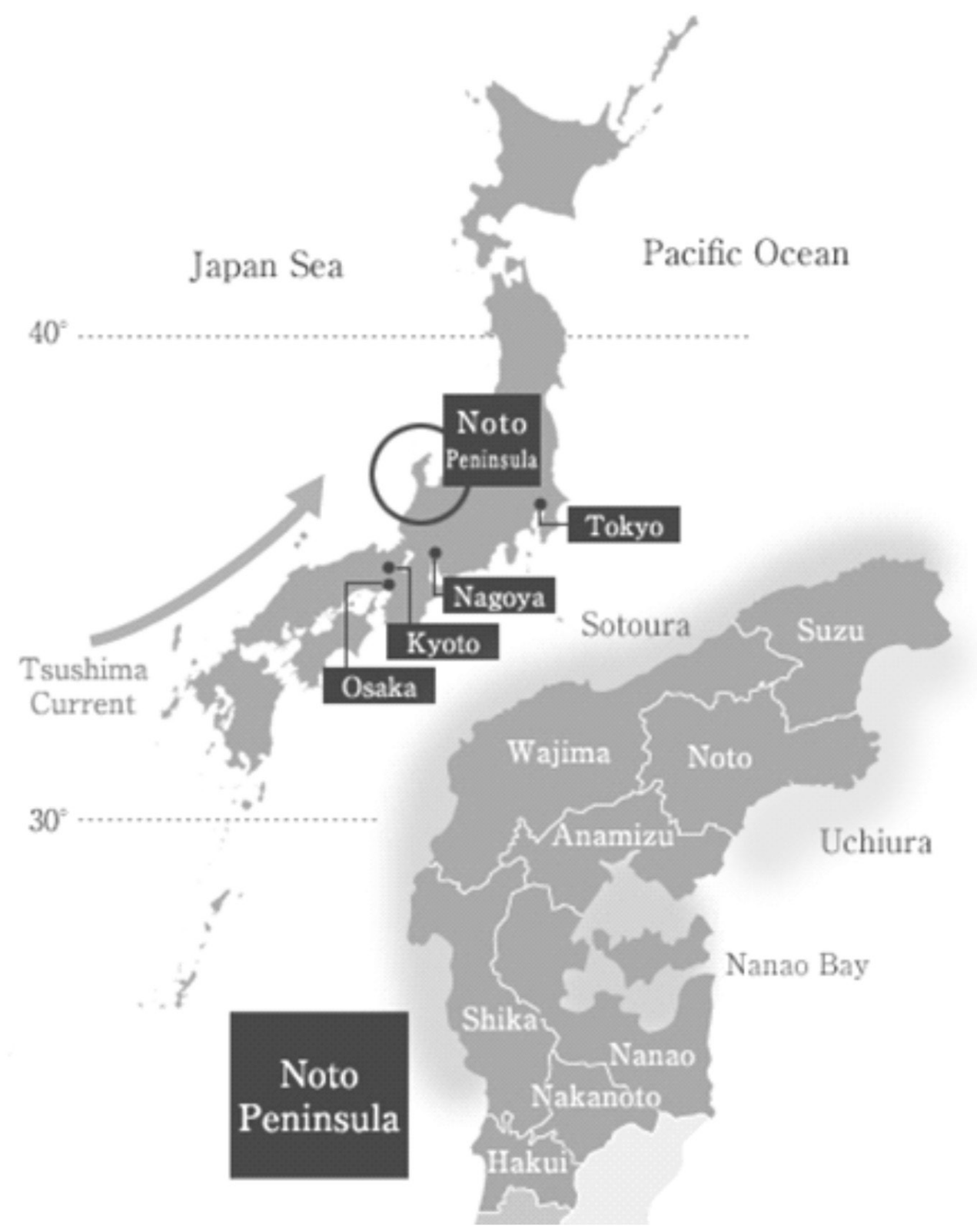

Figure 3. Location of Suzu City

(Source: Noto GIAHS Regional Executive Committee, 2011) 
Data was collected in October and November, 2012; February and March, 2013; May, 2013; and July to September, 2013 in the study site of the Hidaka region. Data was collected in January and February 2013 in the study site of Suzu. Field trips were made to 48 sites of interest, 12 cultural activities were attended. Available documentations and literature were analyzed to determine the historical land use of the Satoyama and Ainu while the interviews were conducted to capture the recent transitions and modern lands use.

\section{Interviews}

In the Hidaka region, key informant interviews were conducted with 27 community members who were identified collaboratively with the Samani Town government and the Hokkaido University Center for Ainu Studies. Participation was voluntary. A total of four household interviews where all family members of the home participated and nine group interviews with a minimum of two persons were conducted (Table 1). Interviews were conducted in Japanese and translated into English with the help of an interpreter.

In Suzu, key informant interviews were conducted with eight community members who were identified collaboratively with the Noto Satoyama Satoumi office. By these means, we aimed to reduce participant self-selection with regard to prior knowledge specifically related to Satoyama. Participation was nevertheless voluntary. A total of four household interviews where all family members of the home participated were conducted (Table 1). Interviews were conducted in Japanese and translated into English with the help of an interpreter.
We used a qualitative analysis approach where the aim was not to produce quantitative data and test hypotheses in a strict sense but to explore phenomena in depth. Grounded theory (Strauss and Corbin, 1998) was employed to analyze the qualitative data. All interviews were digitally recorded and subsequently verbatim transcribed and checked. The categories and sub-categories were identified for both Satoyama and Ainu. The final main coding categories included landscape, ecology and cultural-religious practices.

\section{DISCUSSION \\ Landscape Use}

The description of the structure of the ko$\tan$ (Ainu village) obtained from interviewees coincided with that presented by Watanabe (1973) and is illustrated in Figure 4. The typical kotan was found to be strikingly similar to that of the Satoyama landscape (Figure 5) with areas such as the forest, mountain, river, coast and flatland having specific purposes and uses for their livelihood. Various activities such as agriculture, hunting, fishing and scavenging are practiced in both communities, providing a diet that consists of both gifts of nature and cultured crops.

Rules that were designed to be respected and observed by all, point to the sustainable use of natural resources within the scope of the carrying capacity. In the city of Suzu, residents indicated that the area is divided vertically from the mountains to the sea into various portions. Persons living within their specific portion are allowed to collect edible plants, wood, seaweed and such like but are not allowed to venture into another portion that does not belong

Table 1 Interview Participants: Characteristics

\begin{tabular}{llllll}
\hline \multirow{2}{*}{ Profile } & \multirow{2}{*}{ Characteristic } & & \multicolumn{2}{c}{ Number of Participants } & Total \\
\hline \multirow{2}{*}{ Gender } & Male & 11 & Suzu (n=21) & Hidaka (n=66) & 63 \\
& Female & 10 & 14 & 24 & \\
\multirow{2}{*}{ Age range } & $18-39$ & 6 & 12 & 18 & \\
& $40-59$ & 7 & 39 & 46 \\
& $60+$ & 8 & 15 & 23 \\
\hline
\end{tabular}


to their area of residence. These rules are unspoken in nature and no one in particular enforces them. As Dublin and Tanaka (2014) points out, citizens consciously respect them and do not violate this principle.

This principle occurred in Hokkaido as well, where the various kotans were assigned vertical portions of land thus guaranteeing them access to both hunting and fishing grounds. These divisions were done based on the availability of deer, salmon and certain key plants. This principle of carrying capacity was essential in preventing overfishing and overhunting. Whenever a kotan was considered too large due to an increase in family size, they would make a decision to divide themselves into two different $k o$ tans. A map showing the location of the various Ainu communities prior to the arrival of the Japanese which was seen in the Samani Museum, illustrates this reality (Figure6).

It must be noted that oftentimes various kotans would come together for hunting and fishing expeditions. Permission to hunt, fish or gather in the iwor (territory) of another kotan could be sought and obtained from the village head. The village head would conduct a special ceremony to grant this person permission. This is important because the permission to exploit an area also carried a religious aspect. Any violation of the iwor of another kotan was considered a serious offence and could even carry the death penalty. Anyone who ventured into the iwor of another kotan did so at great personal risk. This is because traps are usually set to catch animals and venturing into an area where the location of such traps is unknown is extremely dangerous. When permission is granted by the village head, the location of all traps is revealed to the individual.
Watanabe (1973) explains that ethnologists have reconstructed the Ainu society as one that was centered on the river systems of inland Hokkaido, in which communities of a few households co-operated in subsistence such as salmon-fishing, deer and bear hunting and the gathering of edible plants.

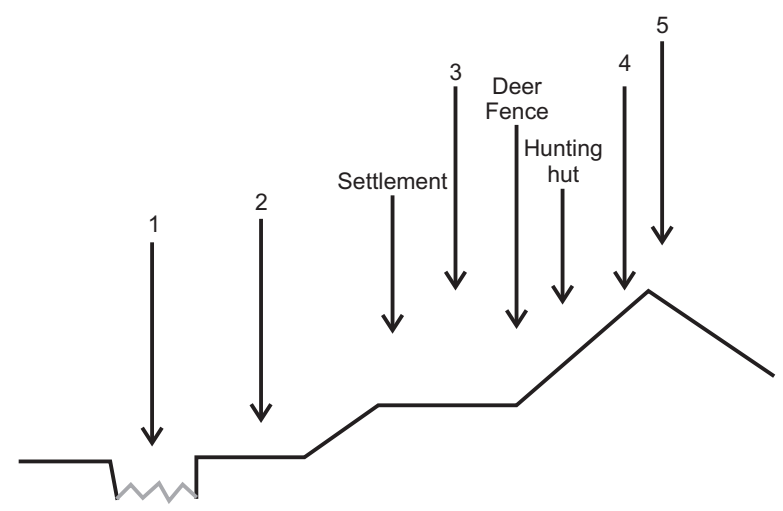

Figure 4. Ainu village (After Watanabe, 1973).

Zone 1: River and tributaries (fishing); Zone 2: River banks (plant collecting and cultivation); Zone 3: River terraces (deer hunting in autumn, plant collecting and habitation); Zone 4: Hillsides along the river course (deer hunting in early winter and spring and occasional and subsidiary bear); Zone 5: Riverhead mountain region (periodic and intensive bear hunting and collection of elm bark).

As Sasaki (2009) points out, there are similarities observed in hunting activities, techniques, equipment, manners, land use, beliefs and world view among peoples in Japan. If one focuses on the ecosystem, then similarities and differences in natural conditions such as flora, fauna, climate and landscape would influence the hunting methods and equipment, ways of land use, and mental attitude to nature while from the perspective of historical and cultural background would be based on the expansion of a people of an ethnic origin or mutual cultural intercourse between ethnic groups. 


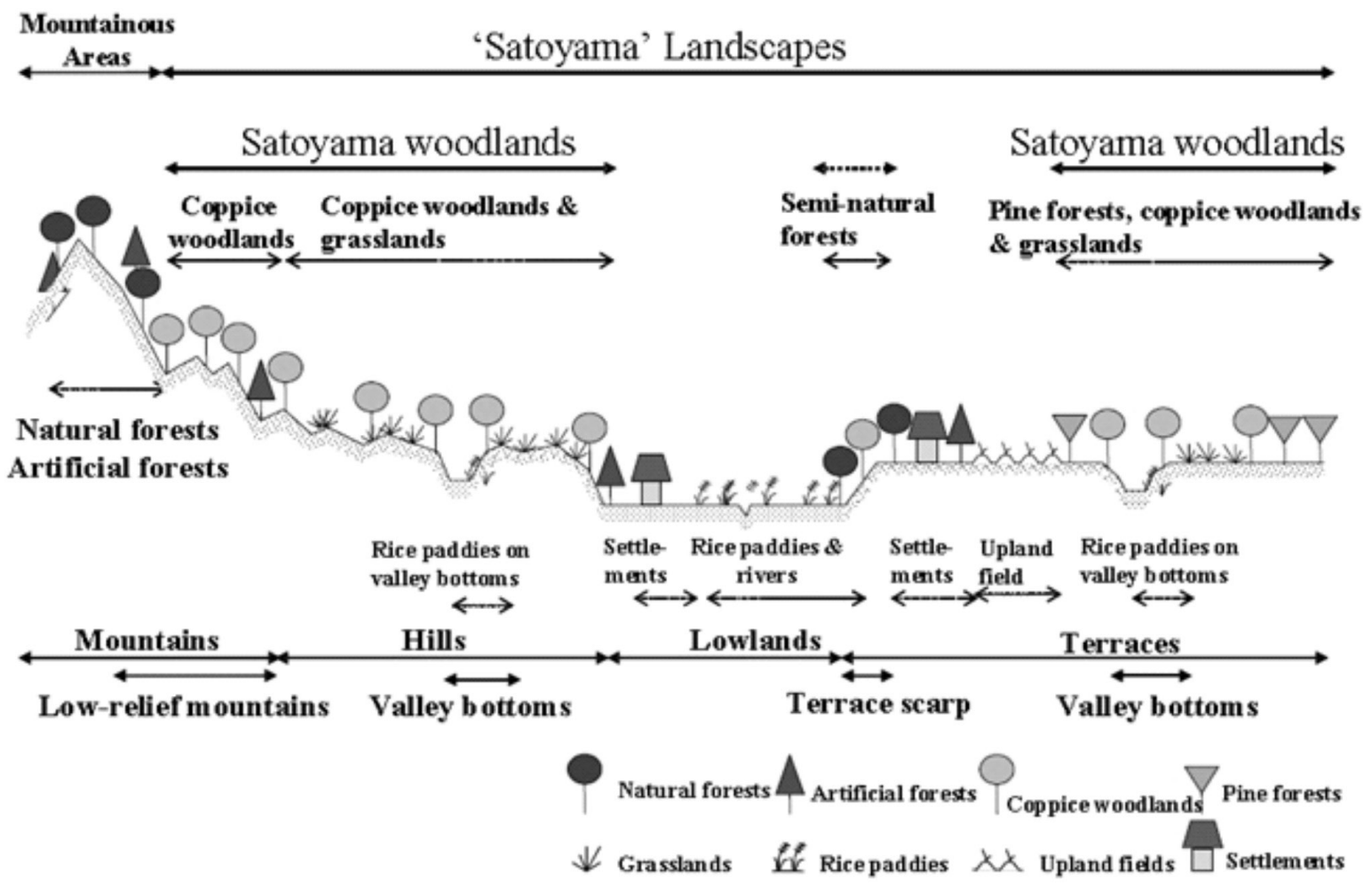

Figure 5. A Transect Schematic representation of satoyama and satoyama landscape

(After Yamamoto, 2001)

The Ainu caught trout in the summer and salmon in the autumn. Spears were used to catch them individually, damming the river was done and then conical basket traps made of bamboo or twigs of willows were used to catch them. Each kotan or individual had a specific river fishing territory. In addition, sea fishing was done in 3 to 4 meter long boats and swordfish, tuna, sunfish and marine mammals such as seals, dolphins and whales were caught. What is an important similarity between the Ainu and Satoyama communities is the fact that fishing rights and zones were in place and there were established fishing seasons (Fitzhugh and Dubreuil, 1999).

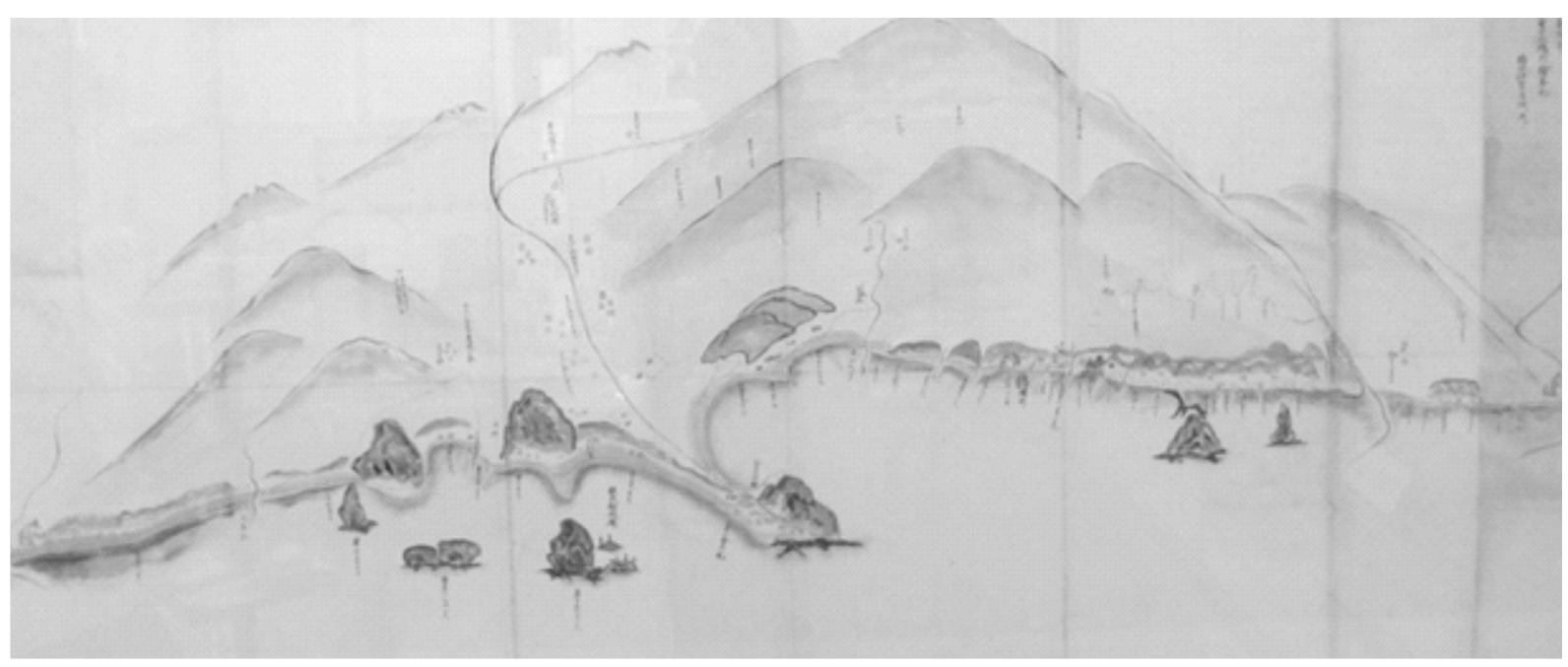

Figure 6. Map showing Ainu Kotans in Samani prior to Japanese arrival (Credits: Samani Library). 
Again, just like fishing, the Ainu had a hunting period which extended from late autumn to early summer and a village possessed a hunting ground of its own or several villages used a joint hunting territory. Heavy penalties were imposed on any outsiders trespassing on such hunting grounds or joint hunting territory. The Ainu hunted bear, Ezo deer, rabbit, fox and raccoon dogs among other animals. They also hunted sea eagles such as white-tailed sea eagles, ravens and other birds. The Ainu hunted with arrows and spears whose points were coated with poison. Traps were also used (Poisson, 2002; Deriha, 2009). Satoyama has mirrored the lifestyles of the Ainu and similar groups. If one were to examine saruyama (the hunting of animals and birds that damage crops, and hare hunting in January and February); sunoyama (communal hunting that targeted the Japanese serow (Capricornis crispus) by Matagi hunters); tateshi (two or three hunters capture a bear sleeping in its den); muratate (communal hunt like sunoyama but with community rules); and denjishsi (no community rules, only participants in the hunt were beneficiaries); one would see a striking similarity between the Japanese hunting villages and the hunting practiced by the Ainu.

In the Satoyamas, the layout and land use in the traditional satoyama is quite similar to that of the Ainu and is closely related to the utilization of surrounding areas. Fallen leaves and underbrush in the forest was converted to compost and returned to the crop fields, firewood and charcoal used for household fuel; mushrooms and vegetables collected for human consumption from the forest (Saito et al. (2012). The gathering of edible plants by Japanese societies close to the forests called zenmai-yama (gathering of edible wild plants in the mountains and in particular royal fern (Osmunda japonica) mirrors that of the Ainu. In the case of the Ainu, women, children, and elderly men incapable of hunting were involved in this activity (Figure 7).

In the Satoyama, agriculture was a pivotal component of the entire system while in the Ainu culture it was more subsistence in nature which followed hunting, fishing and collection of edible plants in terms of importance. Notwithstanding, agriculture was an integral part of the Ainu ecosystem and as can be seen in Fig 4, the same area selected for farming was the identical location preferred in the Satoyama system.

Historical evidence has shown that limited farming was practiced by the Ainu in the southern parts of Hokkaido during the Edo period (1615-1868) as a means of supplementing their diet. In the late nineteenth and early twentieth century however, farming became fully established when these foods became staples (Kohara, 1999).

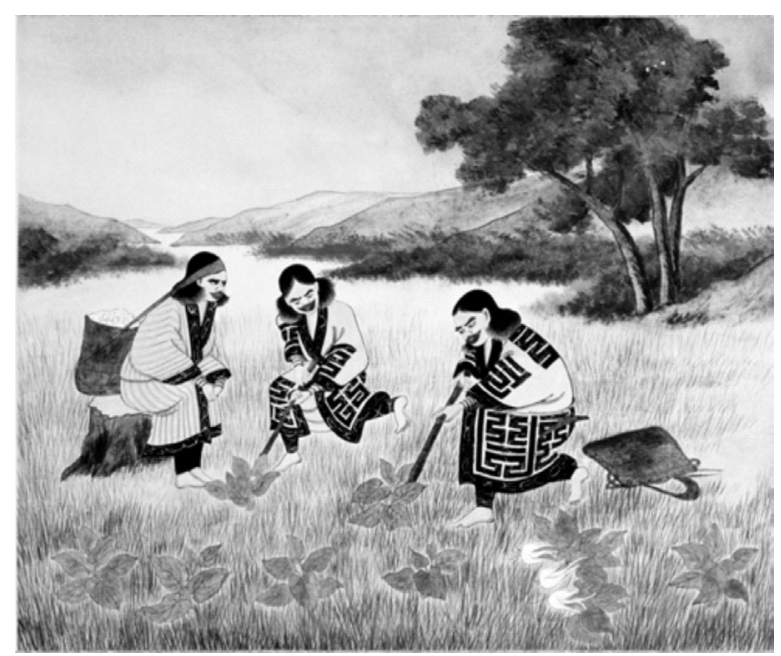

Figure 7. Ainu women involved in the collection of Heartleaf lily [Lilium cordatum]

(Credits: Hakodate Central Library). Note: Original Japanese caption removed

There were essentially two types of farming. Dog farming was done for hunting, sled hauling, companionship, and food. Shifting cultivation was mainly undertaken by women. For cultivation, the Ainu selected land with fewer grasses and trees demonstrating an avoidance of clearing vegetation and tree felling and they frequently selected riverside land. They never fertilized the fields because of their religious attitudes to their gods, nor did they actively weed them (Morris-Suzuki, 1994). 


\section{Cosmological Views of Nature}

The Ainu way of life was characterized by an inseparable and complex spiritual relationship with the land and phenomena of the natural world. Without a doubt, the Ainu regarded the ground in which they lived as sacred. Their beliefs were animistic in nature deeming every physical object to contain a spiritual being whether good or bad (Sugimoto, 2010). The Japanese religious beliefs also present nature as sacred and advocates its reverence and conservation. Shintoism is fairly similar to the Ainu in this regard. The word Shinto ("way of the gods") was adopted, originally as Shindo, meaning "spirit" or kami; and refers to the divinity, or sacred essence, that manifests in multiple forms: rocks, trees, rivers, animals and places. The kami reside in all things (Yamakage, et al., 2006).

The Ainu saw their hunting, fishing and plant gathering as reciprocal in nature. For example, an animal that was hunted actually wanted to be killed and was seen as a spiritual act to legitimize their place in the natural landscape (Walker, 2001). In other words, it was an integration of Ainu, animals and their kamuy (gods, spirits, deities). The Ainu's view of nature as a willing participant in its interaction with man is strikingly similar to the Satoyama concept which views the human- nature interaction as being mutually beneficial thus creating interdependence on both worlds.

Ainu philosophy frowns on wastage, a stark reminder of the Japanese concept of Mottaini, and everything that is collected is supposed to be used meaningfully, if not, the deity in the object cannot return to the world of deities and this will bring suffering to the humans because there will be a lack in the future (Nakamoto, 2004). The maximum utilization of resources is an important component of Satoyama.

\section{Ritual Reactions to Nature}

Animals were considered kamuy and when killed, liberated spirits, and cemented sacred ties to the land. Special rituals were conducted to commemorate and celebrate anything that was taken from the natural environment. While communities shared kinship ties and sometimes for access to hunting territories (iwor), the central focus of that unity was the bear ritual (iyomante) as shown in Figure 8 (Peng and Geiser, 1977). Oftentimes, bear cubs were caught and reared in special cages for this festival underscoring the importance of this festival when one considers the quantity of fish that involved for feeding them.

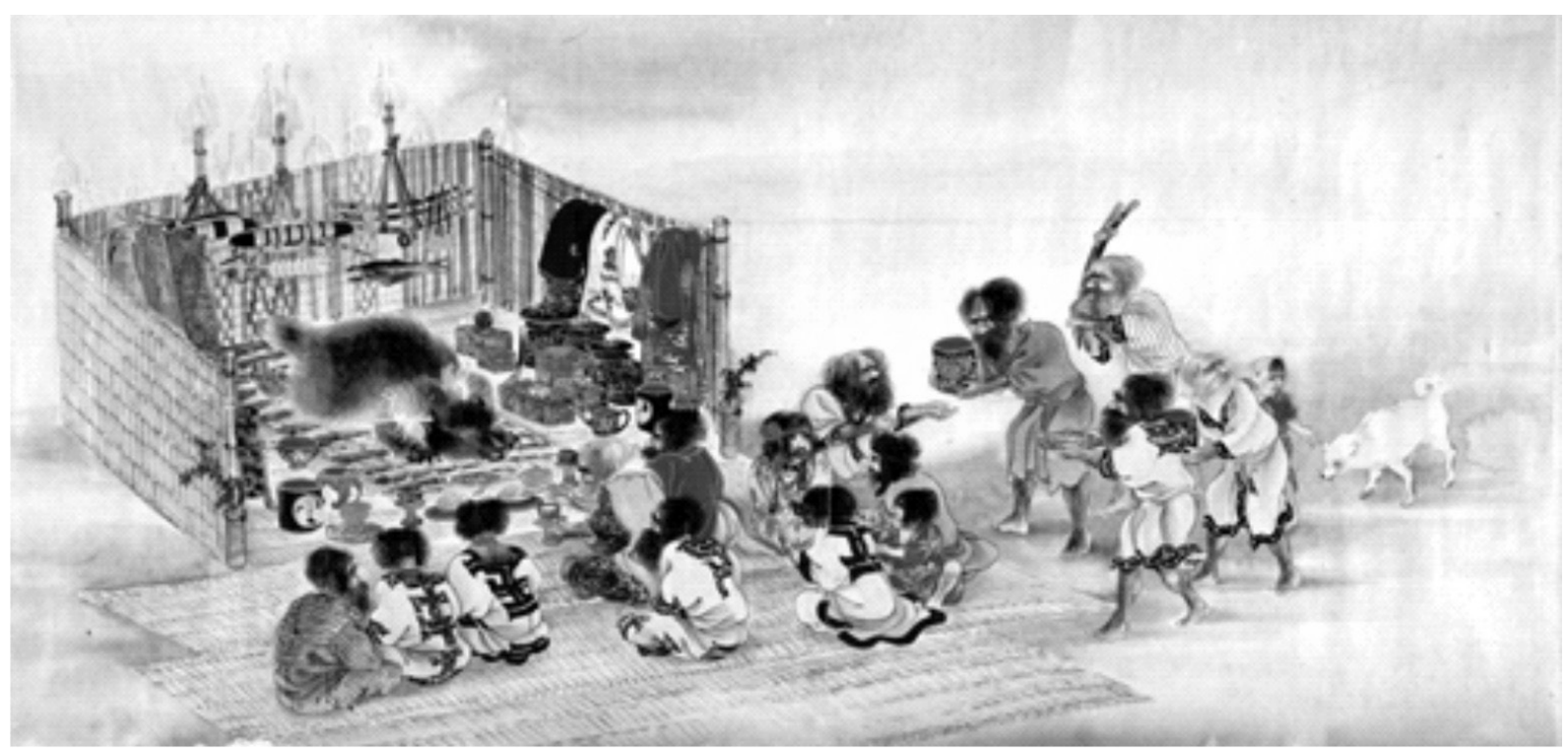

Figure 8. Ainu Bear Festival called Iyomante (Credits: The British Museum) Note: Original Japanese caption removed. 
Results revealed that these Ainu practices and customs were synonymous to those found in Satoyama areas. The agricultural festival of Noto called Aenokoto where the "God of the Rice fields" is accommodated into the homes of residents during the winter and wished farewell in the spring to participate in and give success in the annual rice planting and harvesting was found to be similar to the philosophy of the Ainu of Hokkaido where the kamuy of plants and animals in nature are welcomed when harvested or killed respectively and bid farewell in a Kamuy ceremony.

Aenokoto is an agricultural ritual recognized by UNESCO as an intangible folk cultural asset where, in December after the rice harvest, the master of the house welcomes the deity of the rice paddies into the house accompanied by feasting and thankful offerings. In February, the ritual is repeated to send the deity into the fields to bless and prosper the harvest in the New Year. Because the deity is said to have poor eyesight, it is guided carefully and with lots of respect (Research Institute of City Planning and Communication, 2010). This ritual further reinforces the strong socio-cultural bond between the people and agriculture. Dublin and Tanaka (2014) further pointed out that tombs which were observed in family owned rice fields was indicative and symbolic of the continued support by the ancestors in the annual cultivation of rice. This can also be observed in China as well as in Vietnam (Zeng, 2010). Similarly, in the area of fishing, it was no different. The Ainu celebrated the festival of Asircep-Nomi for the salmon harvest. The Tomobata festival to pay homage to the gods of the sea and for the safety of fishermen is celebrated in Noto city.

\section{CONCLUSIONS}

The study demonstrates that the major difference between Satoyama and the Ainu was the importance placed on agriculture which was on a low scale in the latter due to their traditional and somewhat nomadic lifestyle. The development of Hokkaido resulted in a necessary increase in agriculture in the
Ainu communities since it was no longer possible to live sustainably almost entirely from the gifts of nature. This is important because the same holds true for indigenous peoples globally which often requires drastic changes in their traditional agricultural practices to accommodate new and improved techniques which best guarantees their food supply and survival.

We posit that these commonalities provide a viable entry point for the promotion of Satoyama if it is to be used as a developmental model for promoting the introduction of new, effective and sustainable agricultural practices that are tailored to suit the local culture and existing traditional knowledge, with a view of building sustainable indigenous communities globally, since it is infrequent that modern systems practiced today mirror so closely traditional indigenous culture.

A popular view of Ainu culture is of a people living with nature in a pre-industrial environment, a culture admired as a lost ideal. We posit that Satoyama-Satoumi was the Japanese return to that lost ideal in the case of Hokkaido. In addition, lessons learnt from the development of Hokkaido shows that it is necessary to understand the way of life of the indigenous people in the area which we seek to develop, and facilitate development around their cosmological view of habitat and ritual reactions to it. As this study shows, there are always desirable similarities to be found which can be utilized as a foundation on which any developmental model could be premised.

\section{ACKNOWLEDGEMENT}

The authors wish to thank the people of Hidaka and Noto for their participation and warm hospitality. We are grateful to the $S a$ toyama Satoumi office and Kanazawa University for their technical and logistical support. This study would not have been possible without the kind support of the Ainu community in Hokkaido and the various researchers that have dedicated their career to studying the Ainu way of life. We thank the Japan Science and Technology Agency (JST) who 
funded this research as a part of the strategic program for fostering environmental leaders.

\section{BIBLIOGRAPHY}

Aikoh, T., Hamada, S., Hattori, K., Kaji, K., Kazikawa, H., Kameyama, S., Kaneko, M., Kondo, T., Konno, Y., Mano, T., Matsushima, H., Morimoto, J. Osaki, M., Sajiki, T., Segawa, T., Shoji, A., Shoji, Y., Takayanagi, S., Tsuji, O., Yanagawa, H. and Y. Yoshida. 2012. Hokkaido Cluster, In Satoyama-Satoumi Ecosystems and Human Well-Being, Socio-Ecological Production Landscapes of Japan, edited by Duraiappah, A., K. Nakamura, K. Takeuchi, M. Watanabe, and M. Nishi, pp. 265-281, United Nations University Press, Japan.

Deriha, K. 2009. How can we Approach the Issue of Ainu traps? Ainu Hunting of Small Animals in the NineteenthCentury Fur Trade System, In Human Nature Relations and the Historical Backgrounds of Hunter-Gatherer Cultures in Northeast Asian Forests, edited by Sasaki, S., Senri Ethnological Studies 72: 101-115.

Dublin, D. and N. Tanaka. 2014. The Origin and Meaning of Satoyama: A Peoples Perspective from citizens of Suzu City, Japan, International Multidisciplinary Research Foundation (IMRF), Ratna Prasad Multidisciplinary Research and EducationalSociety, Andhra Pradesh, India. Life Sciences International Research Journal 01 (01): 86-89.

Duraiappah, A. and K. Nakamura. 2012. The Japan Satoyama Satoumi Assessment: Objectives, focus and approach, In Satoyama-Satoumi Ecosystems and Human Well-Being, Socio-Ecological Production Landscapes of Japan, edited by Duraiappah, A., K. Nakamura, K. Takeuchi, M. Watanabe and M. Nishi, pp. 265-281, United Nations University Press, Japan.
Enomoto, M. and N. Kimi. 1990. Hokkaidō no rekishi (2-han). Yamakawa Shuppansha, Tokyo. (in Japnese).

Fitzhugh, W. and C. Dubreuil. 1999. Ainu : spirit of a northern people, Arctic Studies Center, National Museum of Natural History, Smithsonian Institution, Washington, D.C. pp. 202-207.

HokkaidoGovernment. 2013. Hokkaido Regions and Cities, Available at: http://webjpn.org/region/pref/hokkaido.html. Accessed on November 20, 2013.

Howell, D. 1994. Ainu ethnicity and the boundaries of the early modern Japanese state, Past and present 142: 69-93.

Japan Autonomous Academy. 2012. Hokkaido Municipalities, Shimokawa, Hokkaido, Japan.

Kohara, T. 1999. Foods of Choice, In Ainu : spirit of a northern people, edited by Fitzhugh, W. and C. Dubreuil, pp. 202-207, Arctic Studies Center, National Museum of Natural History, Smithsonian Institution, Washington, D.C.

Morris-Suzuki, T. 1994. Creating the frontier: border, identity and history in Japan's far north, EAH 7: 1-24.

Nakamoto, M. 2004. Rediscovering an Appreciation for Ainu Culture, In Circumpolar Ethnicity and Identity, edited by Irimoto, T. and T. Yamada, Senri Ethnological Studies 66: 3-5.

Noto GIAHS Regional Executive Committee. 2011. Noto's Satoyama and Satoumi - Life in Noto, Satoyama Creation Office, Environment Department, Ishikawa Prefectural Government, Japan.

Ono, Y. 1999. Ainu Homelands: Natural history from ice age to modern times, In Ainu : spirit of a northern people, edited by Fitzhugh, W. and C. Dubreuil, pp. 202-207, Arctic Studies Center, National Museum of Natural 
History, Smithsonian Institution, Washington, D.C.

Ohnuki-Tierney, E. 1993. Rice as self: Japanese Identities Through Time, Princeton University Press, Princeton, New Jersey.

Platon, A. 2013. Map of Ainu in Hokkaido (1999), via Wikimedia Commons Available at: http://commons. wikimedia.org/wiki/File\%3AMap_ of_Ainu_in_Hokkaido.svg. Accessed on November 20, 2013.

Poisson, B. 2002. First Peoples: The Ainu of Japan, Lerner Publications Company, Minneapolis. pp. 32-33.

Research Institute of City Planning and Communication. 2010. Traditional knowledge and wisdom of Satoyama/ Satoumi: charcoal and salt making traditions in Ishikawa, Syoseki Company Limited, Kanazawa University, Japan.

Saito, O., H. Shibata, K. Ichikawa, T. Nakamura, Y. Honda and J. Morimoto. 2012, Satoyama and satoumi, and ecosystem services: A conceptual framework, In Satoyama-Satoumi Ecosystems and Human Well-Being, Socio-Ecological Production Landscapes of Japan, edited by Duraiappah, A., K. Nakamura, K. Takeuchi, M. Watanabe and M. Nishi, pp. 265-281, United Nations University Press, Japan.

Sasaki, S. 2009. Human Nature Relations and the Historical Backgrounds of Hunter-Gatherer Cultures in
Northeast Asian Forests, Senri Ethnological Studies 72: 4-14.

Strauss, A. and J. Corbin. 1998. Basics of qualitative research: techniques and procedures for developing grounded theory, 2nd ed. edn, Sage, Thousand Oaks.

Sugimoto, Y. 2010. An introduction to Japanese society, pp. 209-211, Third Edition, Cambridge. Walker, B. 2001. The Conquest of Ainu Lands, Ecology and Culture in Japanese Expansion, 15901800, pp. 17-127, University of California Press, USA.

Walker, B. 2004. Meiji Modernization, Scientific: Agriculture, and the Destruction of Japan's Hokkaidō Wolf, Environmental History 9 (2): 248-274

Watanabe, H. 1973, The Ainu Ecosystem: Environment and Group Structure, University of Washington Press, Seattle

Yamakage, M., P. Leeuw and A. Rankin. 2006. The essence of Shinto: Japan's spiritual heart. Tokyo: Kodansha International.

Yamamoto, S. 2001. Studies on the effect of changes in rural landscape structure on secondary forest plants in Japanese rural areas, Bulletin of the National Institute for Agroenvironmental Sciences 20: 1-105

Zeng, X. 2010. Agricultural view of history of the inhumation custom, Social Sciences, Journal of Jiangxi Normal University 43 (5): 128-141 